\title{
Christian Private Ethics According To 1 Corinthians 15:33 And Its Implications For Christian Youth In Indonesia
}

\author{
Oloria Malau \\ Institut Agama Kristen Negeri Tarutung (Cristian State Intitute Of Tarutung) \\ \{oloriamalau.dra@gmail.com\}
}

\begin{abstract}
Adolescence is an important period in life because it is at this time that humans bridge childhood and adulthood. In addition, adolescence is an important period because this period is also a period: testing, development and expansion. Christian teenagers are now freer than teenagers from previous periods of time. Ethical values among teenagers now seem to have been degraded. Paul in 1 Corinthians 15:33 provides a clear picture for Christian youth in Indonesia not to be deceived and lost because of bad association. Which certainly will have a negative impact and the worst is to lead to destruction. The condition of adolescents who are still unstable causes them to be easily tempted and deceived. Therefore, the ethics of association are very necessary to fortify them from destruction. Where bad association begins because of wrong perceptions that lead them to poor communication and association. Therefore, Christian adolescents in Indonesia still need to need supervision and mentoring to be able to go through their transition to a true maturity both physically and spiritually. And that responsibility is certainly given to families, churches and also PAK teachers in schools.
\end{abstract}

Keywords: ethics, association, youth, 1 Corinthians 15:33

\section{Introduction}

Adolescence is a transition period when children grow up to be adults. That period is also considered to be the most beautiful period. But sometimes adolescence can also be vulnerable if teenagers make the wrong way both in relationships and relationships. Seeing today's teenage relationships, sometimes making the heart feel sad. Karma and ethics, almost no longer known by teenagers. Who is to blame in this case, parents, school, or the environment? How teenagers behave to parents, to teachers, and to fellow friends. It should be a shared concern. Ethical values among teenagers now seem to have been degraded. Problems arise when parents and teachers cannot find ways to convey messages and ethical and moral values to adolescents. Even more worrying, many parents and teachers actually lack ethics.

So what about the association of Christian adolescents today, is there a difference that is seen compared to the association of adolescents in general. Christian teenagers are now freer than teenagers from previous periods of time. This can be seen by the proliferation of teenagers who watch midnight cinema or hangout at the cafe until late at night. This triggers free promiscuity which is being broadcast everywhere. Their association is not only limited to friends but begins to lead to more serious romance. Today's openness of youth about sex matters is very common. Lots of Christian teenagers today are falling into negative things because of 
wrong relationships. Teenagers should also realize which relationships are good and which relationships are not good. Because most Christian teenagers choose relationships, they are only looking for people who can only please them. And if the heart feels happy and comfortable, they feel that it is what they want and do not care if the person they are invited to hang out with is good or not. The difference will be seen if Christian youths associate with people who fear God who have understood how to address or direct their lives on a path that does not deviate from God's will. The attitude of life that is not affected by the situation and conditions that exist, which will bring stability and love of God as said from Psalm 1: 1-2 "Blessed are those who do not walk according to the counsel of the wicked, who do not stand in the way of sinners, and who do not sit in a group of mockers, but his liking is the law of the Lord and contemplates the Torah day and night."

The success of teenagers through the transition period is strongly influenced by biological, cognitive, psychological, and environmental factors. In a day, teenagers, especially Christian teenagers, cannot be separated from associations with other teenagers. Teenagers are required to have social skills to be able to adjust to everyday life. These skills include the ability to communicate, establish relationships with others, listen to opinions / complaints from others, accept / give criticism, act in accordance with the norm and others. Today many adolescents even in Christian youth fall into things that are not good.

Therefore, clear and correct teaching is needed about the ethics of Christian association, especially for Christian youth in Indonesia. Seeing the diversity of tribes, cultures, ethnicities and backgrounds that exist in Indonesia, the teaching on the ethics of Christian association must be acceptable to all groups and not violate applicable norms. So from that the teaching about the ethics of Christian association for Christian adolescents in Indonesia must be taken from the word of God as the source of ultimate truth, precisely in 1 Corinthians 15:33 which reads, "Do not go astray: Bad associations destroy good habits."

\section{Result and Dicussion}

\subsection{Definition of Ethics}

The word Ethics comes from the Greek "ethos" meaning habits, customs. The word ethos means morality, inner feelings, or the tendency of the heart with which someone does an action. In Latin the terms ethos and ethikos are mentioned by the word mos and morality. Therefore the word "ethics" is often associated with the word "moral". In Indonesian the word ethics means morality, derived from the word sila (Sanskrit), meaning: Norms (rules), rules of life, orders. The inner state of the rules of life (attitudes, inner tactics, behavior, manners). This decency will explain and show that the meaning of the word "su" is good, good. So morality is related to good, good. Theologically, ethics moves on the field of decency, meaning morality is related to the norms that should apply, with inner obedience to those norms. Ethics is a normative science group. He shows the problem of what is good. From a quick glance at life, humans recognize that there is no definite thing in this life, unless it is constantly changing. There are changes that are clearly visible, some are difficult to observe. Factors that influence adolescent change include: Internal factors, namely the feeling of curiosity to try, emotions that are still unstable, thoughts that are too idealistic, a sense of solidarity and high spontaneity. Next is external factors, which are sometimes unfriendly environments, friends playing in the home environment, and friends who are in the school environment. Adolescence is an important period 
in life because it is at this time that humans bridge childhood and adulthood. In addition, adolescence is an important period because this period is also a period: Testing, where the values that were previously held without question and doubt are now being questioned in truth and undergoing tests in real life. For example, why can't lie, why not have sexual intercourse before marriage, why not be able to date non-believers. Development, where pieces of knowledge about him begin to be united to form a complete self. What he likes and doesn't like, what he feels or not, is all woven into a picture of himself. Expansion, where teens begin to share themselves with more people and receive more from the environment around them. In fact, how wide a person is depends on how broad the association is. Well, in this context we place adolescent relationships.

\subsection{The principles of adolescent social ethics}

1. Rights and obligations: Rights deserve to be prosecuted, but also not to abandon obligations as social beings.

2. Order and discipline: Always orderly and disciplined in carrying out every activity. Discipline of time so as not to rush.

3. Courtesy: Always maintain good manners, both with peers or parents and also teachers everywhere and at any time.

4. Simplicity: Be simple.

5. Honesty: Honest will bring into truth. Keep being honest even though it's bitter.

6. Justice: Always be fair in getting along. Do not discriminate between friends.

7. Love: Love each other and love friends to avoid hostility.

8. Atmosphere \& association place

\subsection{Understanding Ethics in Relationships}

Social ethics are manners or manners in association that are in accordance with the situation and situation and do not violate the norms that apply both religious norms, politeness, customs, law and others. A good way to behave in relationships is how a person prioritizes polite behavior when dealing with everyone. The world of association is of many kinds. This is influenced by several factors, namely the factors of age, work, attachment, environment and so on. The positive impact of association is being able to form a good personality that can be accepted in various layers so that it can grow and develop into an exemplary individual figure. The negative impact of association is growing into an individual with a deviant personality. Various problems regarding the problem of adolescent association at this time, especially in the country of Indonesia, with its eastern culture which is well-known to understand manners are also rampant.

\subsection{Factors that influence adolescent association}

As social beings, individuals are required to be able to overcome all problems that arise as a result of interaction with the social environment and being able to present themselves in accordance with the rules or norms that apply. Likewise with association in adolescents, there are several factors that can influence it, among others: physical condition, emotional freedom, social interaction, knowledge of one's abilities, self-control of moral and religious values. A wise person says a good friend is a friend who always invites the good way and prevents it from going bad. This is also one of the principles of healthy association. Teenagers are not free to 
associate with anyone, there are certain people who should be included in the list of people who will be shunned, for example friends who use it, friends who try to plunge into acts that violate human law or God's law, or friends who do not build often harassing. The task of parents is to help teens have the right system of criteria so that they can sort friends right.

Christian adolescents may associate with friends who are not believers if the friend is not included in the list of friends who must be shunned, despite different beliefs, teenagers should be allowed to make friends with them. There are many similarities between humans as fellow beings created by God and on the basis of this similarity we can establish strong relationships. They can complement and enrich each other's lives in addition to being a witness to Christ. Adolescents are also permitted to establish close relations with the opposite sex but it is best for teenagers not to establish exclusive romantic relationships until he turns young. There is so much wealth that can only be obtained from group friendships and will immediately disappear if it ties into an exclusive relationship. It's time for teenagers to know the opposite sex in a safe environment that is free of bonding. There are places and activities that teenagers should not visit or do. For example, do not visit brothels, do not watch pornographic films, do not start addictive bad habits such as smoking or drinking liquor, swearing, gambling, etc.

Adolescence is a very critical period, a time to let go of dependence on parents and try to achieve independence so that they can be accepted and recognized as adults. the success of adolescents through the transition period is strongly influenced by biological factors (physical factors), cognitive (intellectual intelligence), psychological (mental factors), and environmental factors. In their daily lives, adolescents cannot be separated from association with other teenagers. adolescents are required to have social skills (social skills) to be able to adjust to everyday life. these skills include the ability to communicate, establish relationships with other people, listen to opinions / complaints from others, give / receive feedback, give / receive criticism, act according to the norms and rules that apply, and others.

\subsection{The basic principle of healthy association}

Healthy association is association that is not trapped in two extreme poles, which are too sensitive (self-closing) or too free. It should be emphasized on positive things, such as to reinforce self-existence or to establish brotherhood and add insight. First, mutual awareness that everyone needs each other and feels right. As is known together that every human being will definitely need other humans. This situation must be well aware, so as not to be the most selfish human being. Second, the relationship provides positive value for both parties. Good relationships are mutually beneficial relationships. In general, everyone does not like to be harmed otherwise. From that one other basis for healthy association is symbiosis of mutualism. Third, mutual respect and respect. One word that must always be remembered if you want to be respected and respected by others, then you must first be able to respect and respect others. Respect and respect for others can be done with many things, such as respecting and respecting the opinions of others, respecting and respecting the way of worship of others, respecting and respecting the customs of others, respecting and respecting the ways of thinking of others and so on. Fourth, not prejudiced. Any religion clearly forbids a person to prejudice others. Because bad prejudice will only bring trouble and hostility to others. The five understand each other's differences. Humans are born with a variety of differences, both in terms of physical, psychological, race, ethnicity, culture and others. Every human being has its own uniqueness, because of this, it must be able to understand these differences. Sixth, give advice to each other. Adolescent social problems can also be used as a means of awakening teenagers by doing activities that are useful for themselves and others, such as representing their respective schools 
in competitions, doing green planting, and so on. With these activities, it can help teens prepare their future.

\subsection{Ethics of Christian Relations according to 1 Corinthians 15:33}

The expression "bad associations ruin good habits" is not exclusively Christian. The same idea also appeared in ancient Greco-Roman literature. Truth in it is wisdom in general. The daily reality shows that someone is determined by who he associates with. Bad associations damage good people. The word ethos (LAI: TB "association") can mean "habit" (LAI: TB) or morality (almost all English versions). Context considerations lead to the last meaning. Not only being advised to have good habits. This is related to behavior errors. The prohibition "Do not go astray" is in the form of present imperative (mē planasthe), thus implying that the prohibited thing has already been done. A more appropriate translation is "Stop being misled". Context considerations also support this meaning. Some congregations have indeed denied the resurrection of the dead $(15: 12)$. So, verse 33 is not a precaution. It's a call to stop from a mistake. The basic planaō can literally refer to a movement heading in the wrong direction or without a clear purpose (read: lost or wandering, Matt. 18:12; Heb. 11:38, see LAI: TB). If used figuratively, this word means "cheated" (the majority of the English version "Don't be deceived"). If Paul is thinking of the meaning of "being deceived" in 1 Corinthians 15:33, it can be concluded that the association error ("bad association") and behavior ("damaging good habits") starts with wrong thinking.

The word do not go astray can be interpreted do not be fooled. Of all types of fraud, selfdeception is the most detrimental; it's like having a traitor in a fortress, who betrays his own country and becomes an enemy. Paul hopes that Christians will not be fooled by:

I. A corrupt heart. A prominent man said once, "Paris is France"; more accurately say, "The heart is human"; "As one thinks in his heart, so does he." The seed contains future flowers, magnificent little oak seeds, poisonous snake eggs; likewise the heart contains the seed of the future of a glorified saint or dead spirit (Matthew 15:19). "Hearts are cheats above all," etc.

II With a contaminated imagination.

The reason why imagination sometimes wanders into the forbidden road is because he is a slave to the heart. The influence of the moon on waves is not more regular and absolute than the influence of the heart on imagination.

III. With people's habits. The phrase "manners" is not used here. Paul's etiquette is meant to mean virtue - all noble and heroic. Do not be fooled. Someone may have the beauty of Venus and the charm of Cleopatra; What are the soft habits of religion? Apple Sodom, has a charming outer appearance, but the inside of the dust; corpses wearing white winding cloth and decorated with flowers that only hide the decay mass. So refinement, polishing, and achievement are often just jewelry from a person who died of transgression and $\sin (1$ Samuel 16: 7). Bad association is interpreted as bad communication. Ethics and courtesy are considered as a result of initial training and religious influence. It might be broken because the tendency of the heart is evil, the world is evil, the exemplary influence is destructive. Therefore there needs to be a decision and supervision. Good habits will definitely be damaged by bad communication. Because the choice of a bad friend shows an evil tendency, a harassing friend, unconsciously lowers morality, destroys shame, and hardens the heart.

The term "evil communication," means associating with bad people. Such evil communication damages the mind, obscures principles, and pollutes behavior. In the case of honest Christians, this tendency, of course, can be neutralized by guarding and praying, and by asking for God's grace. But if, without this defense, a person will freely associate with wicked people, and the effect will immediately be seen in his character. The bad effects of bad 
communication are not described as sudden or striking. Corruption is a gradual change. Secretly, but surely, evil communication is damaging good behavior. Some of the Corinthians might feel self-knowledge or pretentious (cf. 8: 1). They are not selective in joining themselves into a community. In the end they turned out to be not as good as they thought. They begin to be affected. What does "association" (homilia) mean in the context here? Some people try to interpret homilia as limited as conversation (KJV). This is an incorrect translation. Almost all versions understand homilia as "company". Context also seems to support the "association" translation.

\subsection{Implications for Christian Youth in Indonesia}

Adolescents are those who are categorized in the age range of 13-18 years, or generally in Indonesia, so-called adolescents are those who are classified as students at the junior and senior high school level. Teenagers actually do not have a clear place, they are not included in the group of children, but have not yet been fully accepted to enter into the adult group. Teenagers are among children and adults, therefore adolescents are often known as the "seeking identity" phase or "hurricane and storm" phase. Teenagers are still not able to control and function maximally physical and psychological functions. But the adolescent phase is a phase of development that is in a very potential period, both seen from the cognitive, emotional and physical aspects. But on the other hand the age of adolescents belongs to the age group that is susceptible to experiencing various social problems. Based on population projection in 2015, the number of children aged 10-24 years in Indonesia reached more than 66.0 million or $25 \%$ of the total population of Indonesia 255 million (Bapenas, Bps, UNFPA 2013). This figure means that this number is very significant in describing the face of the nation, state and church in the next five to ten years. As is known together, Indonesia is currently entering a demographic bonus period. Where the population is more productive than the young and the elderly. In Indonesia the productive age of the workforce continues to rise every year, and population projections in 2010-2035 show that, Indonesia is now entering the era of demographic bonuses whose peak is expected to occur around 2028-2030.

Demographic bonuses become an opportunity as well as a challenge that must be managed well in order to provide maximum benefits in the future. In the field of employment, bonus demographics must be used optimally through improving the quality of quality human resources. Quality human resources, namely by preparing the younger generation as early as possible (since adolescence) by strengthening self-character, skills (work skills) and equipped with the power of innovation and good creativity. The above challenges cannot be underestimated, especially by the church. The Church needs to take part actively in helping prepare the young generation in this case Christian youth in Indonesia. In addition, the church cannot deny that there are many problems faced by Christian youth besides the demographic bonus challenge. Teenagers are victims of various acts of violence, risk behaviors such as free sex, drug abuse, social media abuse, decreased social awareness among adolescents, increased dropout rates and so on. The church also needs to take a role in actively preparing Christian youth in building awareness as early as possible on various problems experienced such as radicalism, terrorism, damage to the environment in simple and creative ways.

For the church, the existence of adolescents on one side is determined by adult church members, but on the other hand the existence of the church is also determined by the teenager himself. The description of the condition and situation of today's teenagers is a reflection of the condition and face of the church today. Teenagers are not just decorations, or just ornaments for the dynamics of service in the church. Adolescents are part of church members who need to get a proportionate share in the fellowship process. The challenges for the church and adolescents 
themselves which still need to be a common concern, for example, the occurrence of moral degradation, the decline of social care, drug abuse, association and free sex, become victims and perpetrators of violence. Which is all because of bad association among teenagers, including Christian youth in Indonesia. These challenges cannot be faced by adolescents and even the church individually, it requires collaboration, collaboration between churches and parents, as well as schools, in this case PAK teachers, for services for adolescents. Paul in 1 Corinthians 15:33 provides a clear picture for Christian youth in Indonesia not to be deceived and lost because of bad association. Which certainly will have a negative impact and the worst is to lead to destruction. Therefore, Christian adolescents in Indonesia still need to need supervision and mentoring to be able to go through their transition to a true maturity both physically and spiritually. And that responsibility is certainly given to families, churches and also PAK teachers in schools.

\section{Conclusion}

So, as a special conclusion based on the results of research obtained from data analysis is the success of adolescents through the transition period is strongly influenced by biological, cognitive, psychological, and environmental factors. In their daily lives, teenagers, especially Christian teenagers, cannot be separated from relationships with other teenagers. Teenagers are required to have social skills to be able to adjust to everyday life. These skills include the ability to communicate, establish relationships with others, listen to opinions / complaints from others, accept / give criticism, act in accordance with the norm and others. The condition of adolescents who are still unstable causes them to be easily tempted and deceived. Therefore, the ethics of association are very necessary to fortify them from destruction. Where bad association begins because of wrong perceptions that lead them to poor communication and association. Bad association statements destroy habits that are widely accepted, not only in Christianity but also in prevailing norms. Thus Christian adolescents in Indonesia who are rich in diversity must be able to accept and apply the ethics of this Christian association. Of course the role of parents, friends, teachers, church and community is very much needed for adolescents in the form of examples and advice to deal with adolescent social problems. Final words: Educate young people in the way that is appropriate for him, so in his old age he will not turn aside from that path. Proverbs 22: 6

\section{References}

[1] Dr J Verkuyl, Etika Kristen Bagian Umum, BPK Gunung Mulia

[2] _Etika Sexual, BPK Gunung Mulia

[3] Brownlee, Malcolm. Pengambilan Keputusan Etis dan Faktor-faktor di dalamnya, BPK Gunung Mulia

[4] Leon, Xavier. Ensiklopedi Perjanjian Baru, Dufour

[5] Gunarsa, Singgih, D. 1995. Psikologi Praktis: Anak, Remaja dan Keluarga.

[6] Kristanto, Paulus Lilik. Prinsip dan Praktek PAK Penuntun bagi Mahasiswa Teologi dan PAK, Pelayan Gereja, Guru Agama dan keluarga Kristen. Yogyakarta : Andi Offset.

[7] Hurlock, Elisabeth B. Psikologi Perkembangan. Jakarta: Erlangga. 1994

[8] http://utomopaserang.blogspot.com/2014/08/etika-pergaulan-kristen-ditinjau-dari.html

[9] http://baitsuci.blogspot.com/2014/03/pergaulan-yang-benar-menurut-pandangan.html

[10] Bapenas, Bps, UNFPA 2013

[11] https://www.studylight.org/commentary/1-corinthians/15-33.html 
[12] https://www.biblestudytools.com/commentaries/gills-exposition-of-the-bible/1-corinthians-1533.html 